\title{
Analysis of Households Food Insecurity in the Face of Climate Variability: Evidence from North Shewa Zone, Amhara Region, Ethiopia
}

\author{
Debebe Cheber ${ }^{1}$, Fekadu Beyene ${ }^{1}$, Jema Haji ${ }^{2} \&$ Tesfaye Lemma ${ }^{1}$ \\ ${ }^{1}$ Department of Rural Development and Agricultural Extension, Haramaya University, Ethiopia \\ ${ }^{2}$ School of Agricultural Economics and Agribusiness Management, Haramaya University, Ethiopia \\ Correspondence: Debebe Cheber, Department of Rural Development and Agricultural Extension, Haramaya \\ University, Ethiopia. Tel: 251-091-317-7930. E-mail: debebec2012@gmail.com
}

Received: September 18, 2020 Accepted: October 8, 2020 Online Published: October 22, 2020

doi:10.5539/sar.v9n4p43

URL: https://doi.org/10.5539/sar.v9n4p43

\begin{abstract}
Food insecurity is more worrisome now than ever before due to unprecedented climate variability and widespread rural poverty. Research-based and policy relevant empirical evidence is crucial to design strategies to address food insecurity in the face of climate variability. Thus, this study examines the status of food insecurity among households' and its determinants in North Shewa Zone of Amhara Region using cross-sectional data collected from 382 sample households. Households' food insecurity status was determined by comparing the total calorie available for consumption per adult equivalent to the minimum level of subsistence requirement per adult equivalent of $2200 \mathrm{kcal}$. Logistic regression model was used to identify factors that influence food insecurity status of households in the study area. Accordingly, the results of the study show that majority $(56.28 \%)$ of the sample households in the study area were food insecure. In addition, results revealed that age, literacy, cultivated land size, soil fertility status, number of oxen owned and irrigation water use were the major factors negatively associated with food insecurity. In contrast, sex, household size, distance to the main market and rainfall variability have increased the probability of being food insecure. The findings imply that majority of the households are food insecure where its improvement can be addressed through appropriate policy, institutional and technological options.
\end{abstract}

Keywords: household, food insecurity, climate variability, North Shewa Zone, Ethiopia

\section{Introduction}

African countries are at large hit by food insecurity incidence, mainly due to an increase in climate change and variability that led to a decrease in crop yields (HLPE, 2012; Badolo and Romuald, 2015). The effect is particularly pronounced in the rural households of developing countries such as Ethiopia where the capacity to cope with the adverse effect is low (Demeke et al., 2011; Di Falco et al., 2011). As a result, food production is deteriorating to levels that fell short of basic subsistence for many farm households (Gutu et al., 2012). Furthermore, food security situation is worsening and close to a quarter are undernourished largely suffered from chronic hunger (Collier et al., 2008; Di Falco et al., 2011; Jemal and Kim, 2014). According to Brown (2014), the deterioration of food security situations in Ethiopia occurs due to lack of food availability and accessibility hindrances.

Empirical studies have been undertaken to measure the status of food insecurity among households in Ethiopia (Bogale and Shimelis, 2009; Tilksew and Fekaku, 2014; Meles et al., 2016; Mahlet et al., 2018; Seid and Biruk, 2019). Most of these studies analyzed the demographic, physical and natural resource, socio-economic, and institutional factors that affect households' food insecurity but failed to address the climatic factors that are believed to affect households' food insecurity status. This presents an important limitation since household food insecurity is dictated by a host of climate-related factors in combination with demographic, physical and natural resource, socio-economic and institutional factors. Moreover, an empirical study that examined determinants of food insecurity indicates the need to be context specific in identifying factors that influence specific investment in food insecurity projects and programs (Beyene, 2014). 
Therefore, the knowledge of climatic factors could assists policy makers to reduce food insecurity through investing on these factors and also has benefits for mainstreaming climate change and variability issues in designing interventions that have a realistic chance of being implemented, that are more likely contribute to reducing food insecurity situation. Thus, this study examines the status of food insecurity among households' and identifies factors that influence households' food insecurity status in North Shewa Zone of Amhara Region, Ethiopia.

\section{Research Methodology}

\subsection{Description of the Study Area}

The study was carried out in North Shewa Zone of Amhara Region, Ethiopia. The Zone has 22 rural districts in which seven districts are located in highland agro-ecology, 11 in midland agro-ecology and the remaining four in lowland agro-ecology. Its capital is Debre Berhan and has 387 rural and 55 urban kebeles. According to the Central Statistical Agency (CSA) (2013) population projection, North Shewa Zone has a population size of $2,131,857$ persons.

Mixed farming is the dominant livelihood source in the study area. Selling local alcoholic drinks, firewood, charcoal and multipurpose Guassa grass are used to supplement local livelihoods. However, majority of the districts in the study area are food insecure, and the problem is worse in the highland and midland agro-ecological zone (North Shewa Zone Food Security Coordination and Disaster Prevention Office, 2018). According to information from the Zone Food Security Coordination and Disaster Prevention Office, large parts of the study area are beneficiaries of the Productive Safety Nets Program (PSNP). Climate change and variability related risks such as reduced or variable rainfall, warming temperature, crop and livestock pests and diseases, flooding, shortage of water and soil erosion are the major livelihood challenges to farm households of the study area (Alemayehu and Bewket, 2017). Current climate variability contributes to reduced agricultural productivity (Alemayehu and Bewket, 2016), and the future sustainability of the sector in the study area depends on the types of coping and adaptation strategies used by farmers.

The study covered six districts, namely Kewot, Ankober, Menz Keya Gebireal, Asagirt, Tarmaber and Angolelana Tera, of North Shewa Zone (Figure 1). The total population of the six districts is 446,445 out of which 234,415 are males and 212,030 are females. Kewot is in the lowland agro-ecological zone, Ankober, Menz Keya Gebireal and Asagirt are in the midland agro-ecological zone and, Tarmaber and Angolelana Tera are in the highland agro-ecological zone. Elevation ranges from $1853 \mathrm{~m}$ above mean sea level in Kewot to $2473 \mathrm{~m}$ above mean sea level in Angolelana Tera. Some 38.6\% of the total area of the six districts is mountainous, $36.6 \%$ is rugged terrain and $24.8 \%$ is plain lands. Based on the soil classification system, Black cover about $21 \%$ of the districts, Red brown cover about $41 \%$, Red cover $21 \%$, Gray cover $11 \%$ and others account for some $6 \%$. The major land use types include cropland (41\%), forest and bush (22\%), and grazing (5\%). Annual rainfall is $>1000$ $\mathrm{mm}$ and mean annual temperature ranges from $15{ }^{\circ} \mathrm{C}$ in Angolelana Tera to $20{ }^{\circ} \mathrm{C}$ in Kewot (North Shewa Zone Agriculture Office, 2013). 


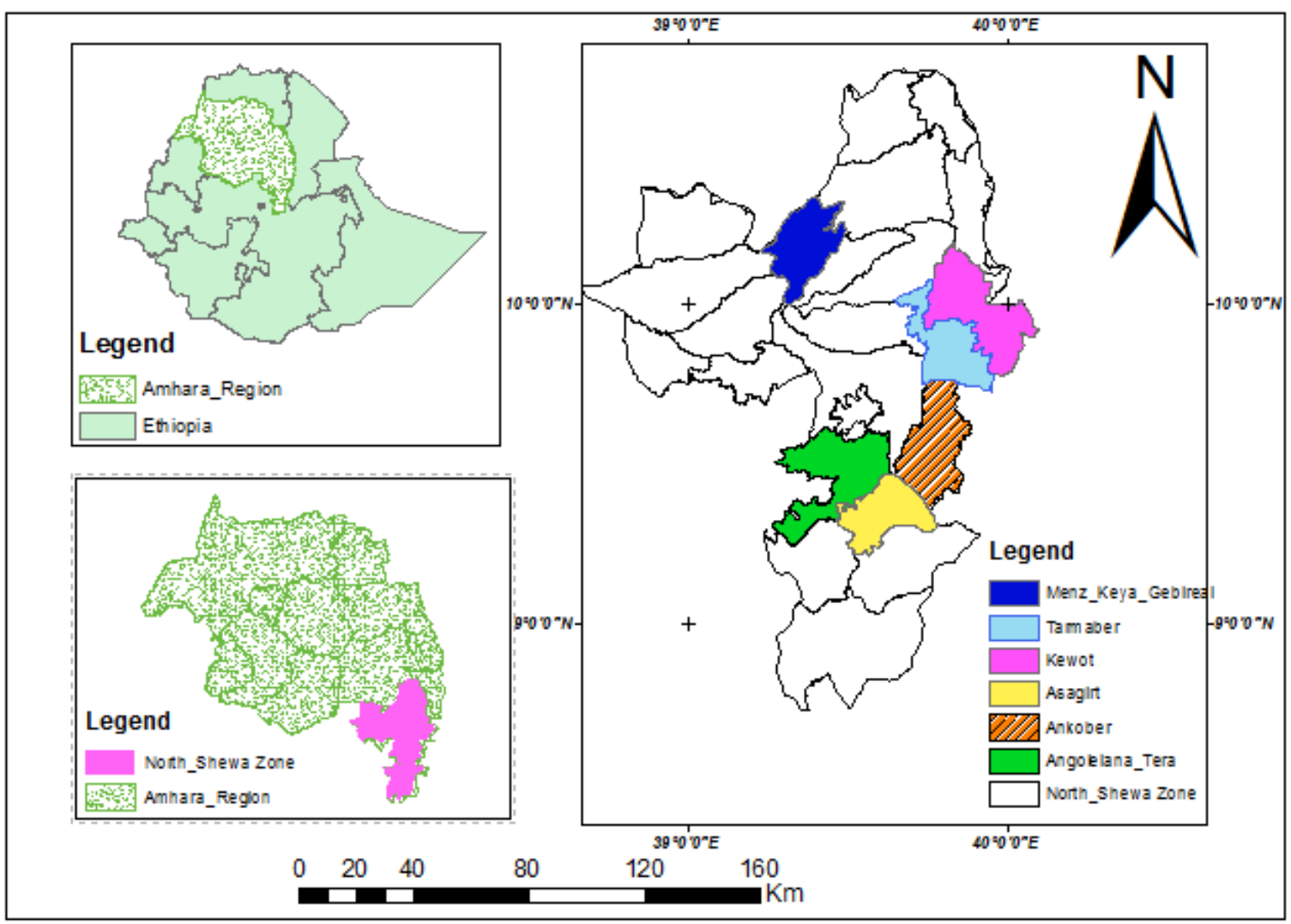

Figure 1. Geographical location of the study area and districts

Source: Extracted from Ethio-GIS, 2018.

\subsection{Sampling Design}

To select representative sample respondents for the household survey, multistage sampling technique was used. First, districts in the zone were clustered based on agro-ecology in to three: highland, midland and lowland. Again, districts of each agro-ecological zone were classified in to two based on frequency of relief recipient (high relief recipient and low relief recipient). Accordingly, from the seven districts located in the highland, three of them were high frequent relief recipients (in thirteen years, the districts received relief more than six times) and the remaining four districts were low frequent relief recipients (received relief less than or equal to six times) for the time period ranging from 2006 to 2018. Likewise, among the eleven districts which are located in the midland, three of them were high frequent relief recipients and the remaining eight districts were low relief recipients. Also, out of the four districts located in the lowland, two districts were high frequent relief recipients and the remaining two districts were low relief recipients.

Therefore, there were six clusters of high relief and low relief recipient districts. Accordingly, from highland, Tarmaber district was high frequent relief recipient and Angolelana Tera from low frequent relief recipient clusters were randomly selected. From midland, Ankober district was high frequent relief recipient and, Asagirt and Menz Keya Gebireal from low frequent relief recipient clusters were randomly selected. From high relief recipient lowland agro-ecology districts, Kewet was also included randomly. The total districts sum up to six: two districts from highland, three districts from midland and one district from lowland agro-ecologies. Finally, a representative kebeles from each districts using simple random sampling technique was selected. Therefore, the total kebeles selected sum up to fifteen (eight kebeles from high relief recipient districts and seven kebeles from low relief recipient districts).

The total sample size was determined using a formula which provides the maximum size to ensure the desired precision using the formula given by Kothari (2004) as follows:

$$
n=\frac{Z^{2} p q N}{e^{2}(N-1)+Z^{2} p q}=\frac{(1.96)^{2}(0.5)(0.5)(76,549)}{(0.05)^{2}(76,548)+(1.96)^{2}(0.5)(0.5)}=382.2467 \approx 382
$$


where, $\mathrm{n}$ is desired sample size; $\mathrm{Z}$ is the standard cumulative distribution that corresponds to the level of confidence with the value of 1.96; $\mathrm{e}$ is the desired level of precision; $\mathrm{p}$ is the estimated proportion of an attribute present in the population, which takes a value of 0.5 as suggested by Israel (1992) to get the desired minimum sample size of households at $95 \%$ confidence level and $\pm 5 \%$ precision; $\mathrm{q}=1-\mathrm{p}$; and $\mathrm{N}$ is the size of the total population from which the sample is drawn. Accordingly, a sample of 382 farm household heads were selected from fifteen kebeles using random sampling with probability proportional to size method.

\subsection{Data Types, Sources and Collection Methods}

The data required for achieving objectives of this research was both quantitative and qualitative in nature. For this purpose, both primary and secondary sources of data was used. Primary data was collected from different category of respondents; household heads, religious leaders, local representatives, kebele leaders and experts in the study area by interview schedule, key informant interview and discussion data collection instruments. To collect other relevant background information, secondary data was used from various sources. Secondary data was obtained from different governmental offices at various levels. Overall, both the quantitative and qualitative data of the study through questionnaire, group discussion and interview was conducted in the following ways;

Both closed and open-ended questions were prepared to generate the required primary household level data. Prior to the actual data collection, the questionnaire was pre-tested (April 2019) to ensure clarity, validity, and sequence of the question with the non-sampled respondents. The pre-testing was employed in three selected districts, one at each agro-ecological district. Based on the result of pre-test, necessary modifications were made and finally, the modified questionnaire was employed to collect data (April-June 2019) from the sampled households. To generate information at the field level, 20 enumerators who know the local language and hold diploma and first degree were recruited and trained on data collection tools and interview handling.

Data from the Focus group discussion (FGD) and key informant interview (KII) were used to complement the information obtained through a household survey in order to have a better understanding of causes of food insecurity and challenges of food security. There were three FGDs held in three randomly selected kebeles, one from each agro-ecological district. The FGDs were composed of 10 participants (religious leaders, local representatives, kebele leaders, male and female household heads). A total of three individuals from three kebeles (one from each agro-ecological district) were selected as a KII. The KII was comprises of one religious leader, one expert with agricultural and environmental background and one kebele leader.

\subsection{Methods of Data Analysis}

Food security at the household level is best measured by direct survey of income, expenditure and consumption and comparing it with the minimum subsistence requirement (Braun et al., 1992). The Ethiopia government has set the minimum acceptable weighted average calorie requirement per adult equivalent (AE) per day at $2200 \mathrm{kcal}$ (FDRE, 2002). The estimation of adult equivalent takes into account age, sex and activity level of each family members in the household. We employed $2200 \mathrm{kcal}$ per adult equivalent per day as a cut-off value between food insecure and food secure households. Thus, those households who have energy per AE below the minimum subsistence requirement $(2200 \mathrm{kcal})$ are deemed to be food insecure, and those who managed to attain $2200 \mathrm{kcal}$ per AE per day are deemed to be food secure households.

Once food insecurity status of each household determined, the next step was analyzing determinant of households' food insecurity status. Different statistical/econometric models can be considered in analyzing determinant of the sampled households' food insecurity status. Following Gujarati (2003), we used logitistic regression model since the dependent variable, food insecurity, was a binary variable which took a value 1 if a household was found to be food insecure and 0 , otherwise. The functional form of logit model can be specified as follows, (Pindyck and Rubinfeld, 1981):

$$
\ln Y=\ln \left(\frac{Y}{1-Y}\right)=\beta_{0}+\beta_{1} X_{1}+\beta_{2} X_{2}+\beta_{3} X_{3}+\cdots+\beta_{m} X_{m}+\mathrm{U}_{i}
$$

where $\ln =$ natural logarithm, $Y=$ probability of being food insecure, $1-Y=$ probability of being food secure, $\beta_{m}=$ coefficients of explanatory variables, $X_{m}=$ predictor variables, and $\mathrm{U}_{i}=$ error term.

\subsection{Variables and Working Hypotheses}

After the analytical procedures are clearly delineated, it is necessary to identify the potential explanatory variables that can influence households' food insecurity. Consequently, theoretical and empirical literatures, and author's knowledge of the food insecurity situation of the study area were used to identify the potential determinants of households' food insecurity. 
The dependent variable of this study is food insecurity, which is a dummy variable taking a value 1 if the household is food insecure and 0 , otherwise. It was estimated using household information concerning type and amount of food item consumed by their families in the last seven days prior to the survey day. The food items were calculated using calorie conversion factor and household member's consumptions were calculated on per AE basis. Then, the amount of total kcal consumed by each sample household was computed and divided by seven days to get daily calorie consumed by the household. This figure is divided by AE of respective households and which finally give the amount of calorie available per AE per day for each sample household and then compared with recommended kcal per AE per day (2200 kcal) (FDRE, 2002). Therefore, those households below this threshold level was categorized as food insecure, otherwise not.

Based on critical review of the literature and author's knowledge of the food insecurity situation of the study area, the following explanatory variables were hypothesized to have an influence on household's food insecurity status:

Age of household head: It is a continuous variable measured in a number of years. Previous study indicated that age has significant effect on household food insecurity (Bogale and Shimelis, 2009). That is, the older the household head, the more experience she/he has in farming and weather forecasting, and become more risk averter. As a result, the chance for such household to be food insecure is low. Therefore, in this study, age of household head was hypothesized to have negative effect on food insecurity.

Sex of household head: It is a dummy variable which can be expressed whether the household head is female or male. It is taken as one determinant of food insecurity with the value of 1 if the household head is female and 0 , otherwise. Literature shows that food insecurity is worse in a female headed households (Tefera et al., 2012). This is because female headed households have less access to improved technologies, credit, land and extension services compared to men (Green, 2000). In addition, women farmers may need a long adjustment period to diversify their income sources fully and become food secure (Christina et al., 2001). However, Abimbola and Kayode (2013) found that female headed households influence food insecurity negatively since they have low family size and dependency ratio. Thus, being female headed household was hypothesized to have positive influence on food insecurity.

Literacy of household head: It is a dummy variable taking a value 1 if the household head is literate and 0 , otherwise. A large body of literature noted that household heads with better educational background are believed to have a chance to diversify household's income sources, adopt improved agricultural practices and technologies, accept technical advice from the extension workers and manage their farm as compared to illiterate ones (Bogale and Shimelis, 2009; Tirfe and Hamda, 2011). In addition, it is assumed that a literate household head often tends to adopt new knowledge, skills and ideas which in turn have a negative effect on food insecurity. Hence, literacy of the household head was expected to have negative effect on food insecurity.

Household size: This variable is measured as a continuous variable by taking the total number of family members in the household. It is then aggregated by employing adult equivalent conversion factors after categorizing the members based on their sex and age. In subsistence economy coupled with limited agricultural technologies, having large family size will demand more food than the labor they contribute to production (Beyene and Muche, 2010; Zemedu and Mesfine, 2014; Gemechu et al., 2016).Therefore, household size was hypothesized to have positive effect on food insecurity.

Dependency ratio: It is a continuous variable measured as the ratio of dependents, household members younger than 15 or older than 64, to the working age of household members, those ages between 15 and 64 (WB, 2013). A household with relatively more dependent members can have a positive effect on the incidence of food insecurity. In other words, a household with more inactive labor force compared to the active labor force shows a high dependency ratio and it is more likely to be food insecure (Bigsten et al., 2002). Therefore, dependency ratio was hypothesized to have positive influence on food insecurity.

Cultivated land size: This variable is taken as a continuous variable measured as the total cropped area in hectares under the household management. Cultivated land is a relevant resource expected to be associated with household's food insecurity status. So that, households with large cultivated land size is expected to produce more than those with small cultivated land. In this connection, Mitiku et al. (2012) indicated in their study that the size of cultivated land and food insecurity have negative relationship. Hence, size of cultivated land was expected to have negative effect on food insecurity.

Soil fertility status: It represents the fertility status of farm land as perceived by farm households, 1 if the soil is fertile and 0 , otherwise. Soil fertility issue is one of the physical factors affecting crop production and availability of food to the household. In this connection, farm households who have no soil fertility problem are 
more likely to be food secure compared to those having soil fertility problem. Ayalneh (2012) indicated in his study that fertility status of plots and household food insecurity have positive relation. Thus, it was expected to have negative influence on food insecurity.

Number of oxen owned: It is a continuous variable measured in number. Oxen are among the most important draft power for land cultivation and basic factors of production for farm operation. In addition, it is used as a means of wealth accumulation in the study area. Households with relatively larger number of oxen can perform better on their crop production and achieve food security. Previous study indicated that number of oxen owned have significant effect on household food security (Muche et al., 2014).Thus, it was hypothesized to have negative influence on food insecurity.

Livestock owned (excluding ox): It is a continuous variable measured by the number of Tropical Livestock Unit (TLU). Livestock in farming household is an asset which helps them to accumulate wealth. In this study livestock ownership refers to the total number of livestock reared by the farm households, which can either be sold or served as a meal. Households with larger number of livestock are able to balance or reduce their food shortage caused by reduction of crop production (Mitiku et al. 2012; Gemechu et al. 2015). Therefore, livestock ownership was hypothesized to have negative effect on food insecurity.

Access to credit service: It is a dummy variable taking the value 1 if the household takes credit and 0 , otherwise. Credit provides the opportunity to use improved agricultural technologies, and this promotes production. Thus, households that have an easy access to credit service have the possibility to invest in on-farm activities and improve their production. As a result, households income and food consumption pattern will improve (Bogale and Shimelis, 2009; Beyene and Muche, 2010). Therefore, it was hypothesized to have negative effect on food insecurity.

Distance to the main market: It is a continuous variable measured in kilometer; it will take from the residence of the household to the main market area. Closeness to the main market area creates access to additional income via off-farm/non-farm employment opportunities, easy access to agricultural information and transportation (Dorward et al., 2003). It is thus, expected that a household located nearer to the main market area has better opportunity to be food secure than a household located farther away from the main market area. Therefore, it was hypothesized to have positive influence on food insecurity.

Irrigation water use: it is a dummy variable that assumes the value 1 if a household is user and 0 , otherwise. Irrigation, as one of technological options available, enables farm households' to produce consumable food crops, diversify their cropping and supplement moisture deficiency in agriculture. Hence, it helps to increase production and food consumption (Van der Veen and Tagel, 2011). Thus, it was expected to have negative effect on food insecurity.

Chemical fertilizer use: it is a dummy variable that assumes the value 1 if a household used chemical fertilizer and 0 , otherwise. Fertilizer use enhances productivity per unit of cultivated land. With this regard, households using fertilizer are expected to have better food production capacity and thereby better food security status than the non-users. Ayalneh (2012) indicated in his study that use of fertilizer and food insecurity have negative relation. Thus, in this study, use of chemical fertilizer was expected to have negative effect on food insecurity.

Total annual income: Income determines the households' access to food. It is an important variable distinguishing the food insecure and food secure households, in that those who have earned relatively larger income from different type sources could be more food secure. According to Mitiku et al. (2012) finding, farmers who have better access to different types of farm income are less likely to become food insecurity than those households who have little access. Therefore, total annual income per AE was expected to have negative effect on food insecurity.

Rainfall variability: Irregularities in weather have adverse consequence in crop production, due to the rain fed nature of agriculture, of Ethiopia (Demeke et al., 2011). Similarly, in this study, rainfall variability is taken to be a deviation from what it supposed to be, like late start or early cessation of the cropping season as well as harvesting time rainfall. Thus, it affects the crop production and causes food shortage to the households. Accordingly, a dummy is created, 1 if the household faced more than two rainfall shocks in the last ten years and 0 , otherwise. Kedir (2017) indicated in his study that frequent rainfall shock and household food insecurity have positive relation. Therefore, it was expected to have positive influence on food insecurity.

Drought: It refers to the agricultural drought including low precipitation, dry land and decreased access to water supplies that inhibit crop and livestock production. It is a dummy variable which takes a value 1 if the household faced more than two drought shocks in the last ten years, which results food shortage, and 0 otherwise. Getachew 
et al. (2018) indicated in their study that frequent drought and household food insecurity have positive relation. Therefore, it was expected to have positive effect on food insecurity.

Flood: It is a dummy variable which takes a value 1 if the household faced more than two flood shocks in the last ten years, which results food shortage, and 0 otherwise. Teshager Assefa (2020) indicated in his study that natural shocks (like flood) and household food insecurity have a positive relation. Therefore, it was expected to have positive influence on food insecurity.

\section{Results and Discussions}

\subsection{Status of Food Insecurity among Households}

We estimated households' food insecurity status by direct survey of consumption and compared with the minimum subsistence requirement per AE per day (i.e. $2200 \mathrm{kcal}$ ). Accordingly, the percentages of food insecure and food secure households were found to be $56.28 \%$ and $43.72 \%$ respectively. The survey indicates that the mean value of the energy available for food insecure and food secure households was $1989.07 \mathrm{kcal} / \mathrm{AE} / \mathrm{day}$ and $2565.39 \mathrm{kcal} / \mathrm{AE} / \mathrm{day}$, respectively. The minimum and maximum energy available for food insecure households was $1509.52 \mathrm{kcal}$ and $2196.52 \mathrm{kcal}$, respectively. Whereas the minimum and maximum energy intakes of food secured households was $2203.11 \mathrm{kcal}$ and $3346.37 \mathrm{kcal}$, respectively. The mean energy intake of all sample households was $2241.02 \mathrm{kcal}$. The $\mathrm{t}$ value confirmed that there was a significant mean difference between food insecure and food secured households at $\mathrm{p}<1 \%$ (Table 1 ).

Table 1 . The association of food energy available for the households with food insecurity status

\begin{tabular}{llllll}
\hline Variable & \multicolumn{3}{c}{ Food Insecurity Status } & \multirow{2}{*}{ t-value } \\
\cline { 3 - 5 } & Food Insecure $(\mathrm{n}=215)$ & Food Secure $(\mathrm{n}=167)$ & Total $(\mathrm{n}=382)$ & \\
\hline Energy available & Minimum & 1509.52 & 2203.11 & 1509.52 & \multirow{2}{2}{$29.90^{* * *}$} \\
per AE per day & Maximum & 2196.52 & 3346.37 & 3346.37 & \\
& Mean & 1989.07 & 2565.39 & 2241.02 & \\
& SD & 158.15 & 218.39 & 341.71 & \\
\hline
\end{tabular}

*** indicate significant at less than $1 \%$ probability level

Source: Household Survey (2019)

\subsection{Association of Explanatory Variables with Households Food Insecurity}

Tables, 2 and 3 present the descriptive statistics result for continuous and dummy variables to observe differences between food insecure and food secure households. The independent t-test shows that there is significant mean difference between food insecure and food secure households with respect to age of household head, household size, dependency ratio, cultivated land size, number of oxen owned, livestock owned, distance to the main market and total annual income. The chi-square analysis shows that large proportion of food insecure households are female headed households, illiterate and having soil fertility problem. The result further indicates that large proportion of food insecure households did not use chemical fertilizer and irrigation water, without access credit services, faced rainfall variability, drought and flood.

Table 2 . The association of continuous variables with households' food insecurity status

\begin{tabular}{|c|c|c|c|c|c|c|c|}
\hline \multirow[t]{3}{*}{ Variables } & \multicolumn{6}{|c|}{ Food Insecurity Status } & \multirow[t]{3}{*}{$\mathrm{t}$-value } \\
\hline & \multicolumn{2}{|c|}{ Food Insecure $(\mathrm{n}=215)$} & \multicolumn{2}{|c|}{ Food Secure $(\mathrm{n}=167)$} & \multicolumn{2}{|c|}{ Total $(n=382)$} & \\
\hline & Mean & SD & Mean & SD & Mean & SD & \\
\hline Age of household head & 44.14 & 8.20 & 48.77 & 8.20 & 46.16 & 8.50 & $5.48 * * *$ \\
\hline Household size & 4.94 & 1.67 & 4.58 & 1.42 & 4.79 & 1.58 & $-2.23 * *$ \\
\hline Dependency ratio & 0.93 & 0.74 & 0.66 & 0.53 & 0.81 & 0.67 & $-4.07 * * *$ \\
\hline Cultivated land size & 1.03 & 0.46 & 1.31 & 0.46 & 1.16 & 0.48 & $5.89 * * *$ \\
\hline Oxen owned & 1.33 & 0.73 & 1.74 & 0.61 & 1.51 & 0.71 & $5.88 * * *$ \\
\hline Livestock owned & 2.61 & 1.53 & 3.19 & 1.57 & 2.86 & 1.57 & $3.64 * * *$ \\
\hline Distance to the main market & 14.03 & 7.71 & 12.70 & 7.87 & 13.45 & 7.80 & $-1.65 * *$ \\
\hline Total annual income & 2838 & 1707 & 4203 & 2005 & 3435 & 1962 & $7.18 * * *$ \\
\hline
\end{tabular}

*** and $* *$ indicate significant at less than $1 \%$ and 5\% probability levels, respectively

Source: Household Survey (2019) 
Table 3. The association of dummy variables with households' food insecurity status

\begin{tabular}{|c|c|c|c|c|c|c|c|c|}
\hline \multirow[t]{3}{*}{ Variables } & \multirow[t]{3}{*}{ Category } & \multicolumn{6}{|c|}{ Food Insecurity Status } & \multirow[t]{3}{*}{$\chi^{2}-$ value } \\
\hline & & \multicolumn{2}{|c|}{$\begin{array}{l}\text { Food Insecure } \\
(\mathrm{n}=215)\end{array}$} & \multicolumn{2}{|c|}{$\begin{array}{l}\text { Food Secure } \\
(\mathrm{n}=167)\end{array}$} & \multicolumn{2}{|c|}{$\begin{array}{l}\text { Total } \\
(\mathrm{n}=382)\end{array}$} & \\
\hline & & $\mathrm{f}$ & $\%$ & $\mathrm{f}$ & $\%$ & $\mathrm{f}$ & $\%$ & \\
\hline \multirow[t]{2}{*}{ Sex of household head } & Male & 154 & 50.16 & 153 & 49.84 & 307 & 100 & $23.80 * * *$ \\
\hline & Female & 61 & 81.33 & 14 & 18.67 & 75 & 100 & \\
\hline \multirow{2}{*}{ Literacy of household head } & Literate & 33 & 34.38 & 63 & 65.63 & 96 & 100 & $25.01 * * *$ \\
\hline & Illiterate & 182 & 63.64 & 104 & 36.36 & 286 & 100 & \\
\hline \multirow[t]{2}{*}{ Soil fertility status } & Fertile & 93 & 43.06 & 123 & 56.94 & 216 & 100 & $35.34 * * *$ \\
\hline & Infertile & 122 & 73.49 & 44 & 26.51 & 166 & 100 & \\
\hline \multirow[t]{2}{*}{ Access to credit service } & Yes & 54 & 46.55 & 62 & 53.45 & 116 & 100 & $6.41 * *$ \\
\hline & No & 161 & 60.53 & 105 & 39.47 & 266 & 100 & \\
\hline \multirow[t]{2}{*}{ Irrigation water use } & Yes & 16 & 21.62 & 58 & 78.38 & 74 & 100 & $44.81 * * *$ \\
\hline & No & 199 & 64.61 & 109 & 35.39 & 308 & 100 & \\
\hline \multirow[t]{2}{*}{ Chemical fertilizer use } & Yes & 108 & 48.87 & 113 & 51.13 & 221 & 100 & $11.71 * * *$ \\
\hline & No & 107 & 66.46 & 54 & 33.54 & 161 & 100 & \\
\hline \multirow[t]{2}{*}{ Rainfall variability } & Yes & 187 & 66.55 & 94 & 33.45 & 281 & 100 & $45.52 * * *$ \\
\hline & No & 28 & 27.72 & 73 & 72.28 & 101 & 100 & \\
\hline \multirow[t]{2}{*}{ Drought } & Yes & 127 & 69.78 & 55 & 30.22 & 182 & 100 & $25.74 * * *$ \\
\hline & No & 88 & 44.00 & 112 & 56.00 & 200 & 100 & \\
\hline \multirow[t]{2}{*}{ Flood } & Yes & 121 & 65.76 & 63 & 34.24 & 184 & 100 & $12.96^{* * *}$ \\
\hline & No & 94 & 47.47 & 104 & 52.53 & 198 & 100 & \\
\hline
\end{tabular}

$* * *$ and $* *$ indicate significant at less than $1 \%$ and $5 \%$ probability levels, respectively

Source: Household Survey (2019)

\subsection{Determinants of Households Food Insecurity Status}

We used logistic regression model to identify the factors that influence households' food insecurity status. Accordingly, variables assumed to have influence on households' food insecurity status in different contexts were tested in the model and out of 17 variables ten of them were found to be significant. The influence of all significant variables were in the expected direction. Table 4 shows the result of the determinants of households' food insecurity status.

The econometric model shows that older household heads are more likely to be food secure than younger ones. This implies that an increase in the age of household head decreases the likelihood for the household to become food insecure. This is possible because as farm households acquire more and more experience in farming operations, accumulate wealth, use better planning and have better chances to become food secure. This result agrees with the prior expectation. The marginal effect of the variable indicates that the probability of being food insecure will decrease by $1.62 \%$ when age of the household head increase by one year. This result is in line with the study conducted by Bogale and Shimelis (2009). They conclude that the increased age of the household head had a negative effect on food insecurity status.

The sign of the coefficient of sex of the household head shows a positive relationship with food insecurity which is statistically significant at $\mathrm{p}<1 \%$. This means that food insecurity incidence is higher in female headed households (by $25.81 \%$ ) compared to those in male headed households. The FGD and key informant information confirmed that many of female headed households in the study area were perceived to be food insecure than male counter parts. The reason could be of less access to improved technologies, credit, land, extension services and need a long adjustment period to diversify their income sources fully and become food secure.

Literacy of household head was found to influence food insecurity negatively and significantly at $\mathrm{p}<1 \%$.The possible explanation is that household head literacy largely contribute on diversifying households income sources, adopting improved agricultural practices and technologies, accepting technical advice from the extension workers and managing farm as compared to the illiterate ones. Thus, being literate reduces the chance of becoming food insecure in the sample households. The marginal effect of the variable reveals that as household head literacy increases, the likelihood of the household to be food insecure will decreases by $21.87 \%$. The finding of this study was found consistent with what had been found by (Adimasu et al., 2019). 
A household with large members is more likely to be food insecure at $\mathrm{p}<1 \%$. The probable reason is that in subsistence agricultural production with limited participation in non-agricultural activities, large household size exerts more pressure on consumption than the labor it contributes to production. The per capita food availability declines as family size increases due to population growth. Hence, large family size is more likely related to being food insecure in a household. The marginal effect of the variable reveals that as household size increases by one unit, the likelihood of the household to be food insecure will increases by $10.29 \%$. This result is also in agreement with the study conducted by Mahlet et al. (2018). They reported that households with large size have a higher possibility of being food insecure than those with smaller size, and vice versa.

Cultivated land size was significantly and negatively associated with food insecurity at $\mathrm{p}<10 \%$. This association reveals that households owned larger land size are more likely to be food secure than households which owned small land size. The possible justification is that farm households which had larger farm size had better chance to produce more, to diversify the crop they produce and also have got larger volume of crop residues. The marginal effect of the variable shows that as the area under cultivation is increased by 1 ha, the likelihood of the household to be food insecure will decreased by $15.82 \%$. The finding of this study was found consistent with what had been found by (Bogale and Shimelis, 2009; Beyene and Muche, 2010).

The result of logit model showed that soil fertility status has a significant $($ at $p<5 \%)$ and negative influence on food insecurity. This result is completely in agreement with the prior expectation. This might be the fact that better soil quality of a given farm land results in better production and increases the likelihood of the household to be food secure. The marginal effect of the variable reveals that as the fertility status of a farm land increases, the likelihood of the household to be food insecure will decreases by $18.6 \%$.

The relationship between the number of oxen owned and food insecurity turned out to be negative and significant at $\mathrm{p}<5 \%$. This is an indication that ownership of oxen acts as a hedge against food insecurity in the study area. Oxen, besides its direct contribution to crop production as the main source of draft power, is a vital means of wealth accumulation that can be consumed during times of need, especially when food stock in the household deteriorates. The marginal effect of the variable reveals that as the number of oxen owned increases by one unit, the likelihood of the household to be food insecure will decrease by $13.44 \%$. The finding of this study was found consistent with what had been found by Mahlet et al. (2018).

Table 4. The logistic regression model results for the determinants of food insecurity status

\begin{tabular}{|c|c|c|c|c|c|}
\hline Variables & Coef. & Std. Err. & $\mathrm{z}$ & $\mathrm{P}>\mathrm{Z}$ & Marginal effect \\
\hline Age of household head & -0.0669 & 0.0179 & -3.73 & $0.000 * * *$ & -0.0162 \\
\hline Sex of household head & 1.1924 & 0.4363 & 2.73 & $0.006 * * *$ & 0.2581 \\
\hline Literacy of household head & -0.8928 & 0.3336 & -2.68 & $0.007 * * *$ & -0.2187 \\
\hline Household size & 0.4244 & 0.1164 & 3.65 & $0.000 * * *$ & 0.1029 \\
\hline Dependency ratio & 0.1188 & 0.2372 & 0.5 & 0.616 & 0.0288 \\
\hline Cultivated land size & -0.6527 & 0.3870 & -1.69 & $0.092 *$ & -0.1582 \\
\hline Soil fertility status & -0.7835 & 0.3309 & -2.37 & $0.018^{* *}$ & -0.1860 \\
\hline Number of oxen owned & -0.5545 & 0.2481 & -2.24 & $0.025^{* *}$ & -0.1344 \\
\hline Livestock owned & 0.0165 & 0.1080 & 0.15 & 0.879 & 0.0040 \\
\hline Access to credit service & -0.1144 & 0.3079 & -0.37 & 0.71 & -0.0278 \\
\hline Distance to the main market & 0.0503 & 0.0200 & 2.52 & $0.012 * *$ & 0.0122 \\
\hline Irrigation water use & -1.1699 & 0.4077 & -2.87 & $0.004 * * *$ & -0.2844 \\
\hline Chemical fertilizer use & -0.0716 & 0.3378 & -0.21 & 0.832 & -0.0173 \\
\hline Total annual income & -0.0001 & 8.6E-05 & -1.5 & 0.132 & $-3.15 \mathrm{E}-05$ \\
\hline Rainfall variability & 0.9494 & 0.4013 & 2.37 & $0.018^{* * *}$ & 0.2321 \\
\hline Drought & 0.1335 & 0.3102 & 0.43 & 0.667 & 0.0323 \\
\hline Flood & 0.1840 & 0.3053 & 0.6 & 0.547 & 0.0446 \\
\hline Constant & 2.5103 & 0.9907 & 2.53 & 0.011 & \\
\hline Log likelihood & -168.4896 & & & & \\
\hline Number of obs & 382 & & & & \\
\hline $\operatorname{LR} \chi^{2}(17)$ & 186.54 & & & & \\
\hline Prob $>\chi^{2}$ & 0.0000 & & & & \\
\hline Pseudo $R^{2}$ & 0.3563 & & & & \\
\hline
\end{tabular}

$* * *, * *$ and $*$ indicate significant at less than 1,5 , and $10 \%$ probability levels, respectively

Source: Household Survey (2019) 
As shown in Table 4, the coefficient of distance to the main market was statistically significant at $\mathrm{p}<5 \%$ and exhibited a positive association with food insecurity. This shows that, households who are closer to the main market are more likely to be food secure than those who are farther away from the main market. This could be because households closer to the main market creates access to additional income via off-farm/non-farm employment opportunities, easy access of selling their produce and purchase food from the market and encouraged to diversify and produce marketable products. The marginal effect of the variable reveals that as distance to the main market increases by one unit, the likelihood of the household to be food insecure will increases by $1.22 \%$. This result is in conformity with the findings of Getachew et al. (2018).

Moreover, Table 4 indicates that irrigation water use is negatively and significantly (at $\mathrm{p}<1 \%$ ) associated with food insecurity. The negative association indicates that households who have used irrigation on their farm are more likely to be food secure than those did not use. This is mainly because irrigation water use enables households to produce more than one crop per year, increase their income and consumption levels and diversify their cropping systems. The marginal effect of the variable reveals that if use of irrigation water by the household increases, the likelihood of the household to be food insecure will decreases by $28.44 \%$. A similar relation was observed by other studies (Tirfe and Hamda, 2011; Getachew et al., 2018).

Rainfall variability was significantly and positively associated with food insecurity at $p<5 \%$. The positive association indicates that households that have experienced rainfall shock are more likely to be food insecure when it is compared to those which were not experiencing the rainfall shock. This is due to the fact that rainfall shock could result in crop failure that impedes the availability of food and reduce income that the households could have earned from their production. The marginal effect of the variable reveals that as the experience of rainfall shock increases, the likelihood of the household to be food insecure will increases by $23.21 \%$. The finding of this study was found consistent with what had been found by Kedir (2017).

\section{Conclusion and Implications}

The findings show that, large proportion of the study participants were food insecure. We found that, older household head, literacy of household head, large cultivated land size, better soil fertility, sufficient oxen ownership and use of irrigation water have a negative influence on the state of household food insecurity. Meanwhile, large household size, larger distance to the main market and frequent occurrence of rainfall variability have increased the chance of being food insecure household. In whole, household-related factors determine household food insecurity through influencing own production and household purchasing power of food in study area.

The findings clearly indicate the role of demographic features of the household (age, sex, literacy and household size) in contributing to food insecurity. Therefore, intervention that involve aged household heads enable to share their life long experience to younger household heads should be devised and implemented. Government as well as non-governmental organizations needs to focus more specifically on female headed household and provide them with social security allowance as most of them are poor and do not have other employment opportunity. Furthermore, the regional and federal governments should provide access to education for farmers (both formal and informal) should be strengthened. Likewise, proper attention should be given to limit the number of family members in the household. This could be achieved by proper awareness creation on practicing family planning.

Moreover, the results also imply that the size of cultivated land, soil fertility status and number of oxen owned can immensely contribute to declining food insecurity. Policies and strategies that involve regulation of the use of appropriate land use system, access and use of agricultural technologies, supporting farmers to increase their oxen and, introducing necessary adjustments are essential to sustain the desirable effects of these practices on food insecurity. Also, government and non-governmental organizations can play their role in providing and developing a linkage between the producer and consumer and this can be alleviated by establishment of market centers in farming areas, form cooperatives and support infrastructure development programs.

From the model results, we learn that technical interventions enhancing small scale ground water irrigation practices of farmers reinforce the desirable effects of these practices on food insecurity. Besides, it can be observed that frequent occurrence of rainfall variability is found to have statistical significance in making households food insecure. Therefore, promotion of conservation technologies, which helps the agricultural land maintain productivity and provide economic, environmental, and social benefits at farm level, would be the policy agenda to improve food security situation of the study area. In general, the results of this study produce the implication that reduce food insecurity in North Shewa Zone of Ethiopia requires adoption of mixed policies and strategies along those variables found to have a significant effect on food insecurity. 


\section{Acknowledgements}

The authors would like to thank Ministry of Science and Higher Education (MoSHE) for financial support of this research. Moreover, we warmly thank the sample respondents, enumerators and district experts for their valuable response during data collection process.

\section{References}

Abimbola, O., \& Kayode, A. (2013). Food insecurity status of rural households during the post-planting season in Nigeria. Journal of Agriculture and Sustainability, 4(1), 16-35.

Adimasu, A., Senbetie, T., \& Yoseph, H. (2019). Assessment of food insecurity and its determinants in the rural households in Damot Gale Woreda, Wolaita Zone, Southern Ethiopia. Food and Agriculture, 8(11), 1-11. https://doi.org/10.1186/s40066-019-0254-0

Alemayehu, A., \& Bewket, W. (2017). Smallholder farmers' coping and adaptation strategies to climatic change and variability in central highlands of Ethiopia. The International Journal of Justice and Sustainability, 22(7), 825-839. https://doi.org/10.1080/13549839.2017.1290058

Alemayehu, A., \& Bewket, W. (2016). Local climate variability and crop production in the central highlands of Ethiopia. Environmental Development, 19, 36-48. https://doi.org/10.1016/j.envdev.2016.06.002

Ayalneh, B. (2012). Vulnerability of smallholder rural households to food insecurity in Eastern Ethiopia. Food Science, 4, 581-591. https://doi.org/10.1007/s12571-012-0208-x

Badolo, F., \& Romuald, S. (2015). Climatic variability and food security in developing countries. HAL Id: halshs-00939247v2.

Beyene, F. (2014). Determinants of food security under changing land-use systems among pastoral and agro-pastoral households in Eastern Ethiopia. Environmental Development and Sustainability, 17(5), 1163-82. https://doi.org/10.1007/s10668-014-9596-8

Beyene, F., \& Muche, M. (2010). Determinants of food security among rural households of central Ethiopia: An empirical analysis. Quarterly Journal of International Agriculture, 49(4), 299-318.

Bigsten, A., Kebede, B., Shimelis, A., \& Taddesse, M. (2002). Growth and poverty reduction in Ethiopia: Evidence from household panel surveys. World Development, 31(1), 87-106. https://doi.org/10.1016/S0305-750X(02)00175-4

Bogale, A., \& Shimelis, A. (2009). Household level determinants of food insecurity in rural areas of Dire Dawa, Eastern Ethiopia. African Journal of Food, Agriculture, Nutrition and Development, 9(9), 1914-1926.

Braun, J. V., Bouis, H, Kumar, S., \& Pandya-Lorch, R. (1992). Improving Food Security of the Poor: Concept, Policy, and Programs. International Food Policy Research Institute. Washington, DC.

Brown, M. E. (2014). Food Security, Food Prices and Climate Variability. Routledge, London and New York. https://doi.org/10.4324/9780203071687

Christina, H., Thomson, M., Jennifer, S., \& Anderson, S. (2001). Addressing food security in Africa via multiple livelihood strategies of women farmers. Journal of Food Policy, 26(1), 177-207. https://doi.org/10.1016/S0306-9192(00)00045-2

Collier, P., Conway, G., \& Venables, T. (2008). Climate change and Africa. Oxford Review of Economic Policy, 24(2), 337-353. https://doi.org/10.1093/oxrep/grn019

CSA (Central Statistical Agency). (2013). Population Projection of Ethiopia for All Regions at Woreda Level from 2014-2017. Addis Ababa, Ethiopia.

Demeke, A., Keil, A., \& Zeller, M. (2011). Using panel data to estimate the effect of rainfall shocks on smallholders' food security and vulnerability in rural Ethiopia. Climatic Change, 108(1), 185-206. https://doi.org/10.1007/s10584-010-9994-3

Di Falco, S., Veronesi, M., \& Yesuf, M. (2011). Does adaptation to climate change provide food security? A micro-perspective from Ethiopia. American Journal of Agricultural Economics, 93(3), 829-846. https://doi.org/10.1093/ajae/aar006

Dorward, A., Poole, N., Morrison, J., Kydd, J., \& Urey, I. (2003). Markets, institutions and technology: Missing links in livelihood analysis. Development Policy Review, 21(3), 319-332.

https://doi.org/10.1111/1467-7679.00213 
FDRE (Federal Democratic Republic of Ethiopia). (2002). Food Security Strategy. Addis Ababa, Ethiopia.

Gemechu, F., Zemedu, L., \& Yousuf, J. (2015). Determinants of farm household food security in Hawi Gudina district, West Hararghe Zone, Oromia Regional State, Ethiopia. Journal of Agricultural Extension and Rural Development, 8(2), 12-18. https://doi.org/10.5897/JAERD2014.0660

Getachew, T., Degefa, T., \& Negussie, S. (2018). Food insecurity of rural households in Boset district of Ethiopia: A suite of indicators analysis. Agriculture and Food Science, 7(1), 1-16. https://doi.org/10.1186/s40066-018-0217-x

Green, W. H. (2000). Econometric Analysis (4th ed.). New Jersy, Prentice-hall, Inc.

Gujarati, D. N. (2003). Basic Econometrics (4th ed.). McGraw-Hill, New York.

Gutu, T., Emana, B., \& Ketema, M. (2012). Analysis of vulnerability and resilience to climate change induced shocks in North Shewa, Ethiopia. Agricultural Sciences, 3(6), 871-888. https://doi.org/10.4236/as.2012.36106

HLPE (High Level Panel of Expert). (2012). Food Security and Climate Change. A Report by the High Level Panel of Experts on Food Security and Nutrition of the Committee on World Food Security, Rome.

Jemal, A., \& Kim, K. (2014). Determinants of household food security in rural Ethiopia: An empirical analysis. Journal of Rural Development, 37(2), 129-157.

Kedir, H. (2017). Determinants of food security: Evidence from Ethiopian Rural Household Survey (ERHS) using pooled cross-sectional study. Agriculture and Food Science, 7(1), 1-7.

Kothari, C. R. (2004). Research Methodology: Methods and Techniques (2nd ed.). New Age International, New Delhi, India.

Mahlet, M., Gebeyaw, T., \& Zewdie, A. (2018). Magnitude and associated factors of household food insecurity in Fedis Woreda East Hararghe Zone, Oromia Region, Ethiopia. Journal of Agriculture and Food Security, 7(3), 1-8. https://doi.org/10.1186/s40066-017-0140-6

Meles, T., Meseret. A., \& Miruts. M. (2016). Assessment of food security status and factors influencing food security in Hawi Guddina district, Ethiopia. International Journal of Agricultural Extension and Rural Development, 3(3), 167-173.

Mitiku, A., Fufa, B., \& Tadese, B. (2012). Empirical analysis of the determinants of rural households' food security in southern Ethiopia: The case of Shashemene District. Basic Research Journal of Agricultural Science and Review, 1(6), 132-138.

Muche, M., Birara, E., \& Tesfalem, K. (2014). Determinants of food security among Southwest Ethiopia rural households. Food Science and Technology, 2(7), 93-100.

North Shewa Zone Agriculture Office. (2013). North Shewa Zone Wereda Basic Data (Amharic Version, Unpublished Data). Debre Berhan, Ethiopia.

North Shewa Zone Food Security Coordination and Disaster Prevention Office. (2018). Annual report for the year 2017/18 (Amharic Version, Unpublished Report). Debre Berhan, Ethiopia.

Pindyck, S., \& Rubinfeld, L. (1981). Econometric Models and Economic Forecasts (2nd ed.). McGraw-Hill, New York.

Seid, S., \& Biruk, K. (2019). Analysis of household's food insecurity and its coping mechanisms in Western Ethiopia. Journal of Agricultural and food economics, 5(7), 1-20. https://doi.org/10.1186/s40100-019-0124-x

Tefera, B., Lindstrom, D., Abebe, G., Jira, C., Hattori, M. K., Lachat, C., Huybregts, L., \& Kolsteren, P. (2012). Predictors of chronic food insecurity among adolescents in Southwest Ethiopia: A longitudinal study. BMC Public Health, 12(1), 1-14. https://doi.org/10.1186/1471-2458-12-604

Teshager, A. (2020). Household level food insecurity assessment: Evidence from panel data, Ethiopia. Science African, 7(1), 1-9. https://doi.org/10.1016/j.sciaf.2019.e00262

Tilksew, G., \& Fekadu, B. (2014). Factors influencing rural household food insecurity: The case of Babile District, East Hararghe Zone, Ethiopia. Journal of Development and Agricultural Economics, 6(4), 149-158. https://doi.org/10.5897/JDAE12.154

Tirfe, Z., \& Hamda, H. (2011). Farm households' food insecurity, determinants and coping strategies: The case 
of Fedis District, Eastern Oromia, Ethiopia. Journal of Agricultural Economics, 8(1), 1-35.

Van der Veen, A., \& Tagel, G. (2011). Effect of policy interventions on food security in Tigray, Northern Ethiopia. Ecology and Society, 16(1), 18. https://doi.org/10.5751/ES-03895-160118

WB (World Bank). (2013). The United Nations Population Division's World Population Prospects. World Development Indicators, Census Report.

Zemedu, L., \& Mesfin, W. (2014). Smallholders' vulnerability to food insecurity and coping strategies: In the face of climate change, East Hararghe, Ethiopia. Journal of Economics and Sustainable Development, 5(24), 86-101.

\section{Copyrights}

Copyright for this article is retained by the author(s), with first publication rights granted to the journal.

This is an open-access article distributed under the terms and conditions of the Creative Commons Attribution license (http://creativecommons.org/licenses/by/3.0/). 